\title{
$\mathrm{PC}$ クラスタ環境のための 3 次元モデル軽量化手法の分散化
}

\author{
吉田 安男 $*_{1}$ 今野 晃市 $*_{2}$ 德山 喜政 $*_{3}$ \\ $*_{1}$ (株) プレミアムエージェンシー $\quad *_{2}$ 岩手大学工学部 $*_{3}$ 東京工芸大学工学部
}

\section{A Distributed Simplification Method with PC Cluster}

\author{
Yasuo Yoshida* $_{1} \quad$ Kouichi Konno*2 $\quad$ Yoshimasa Tokuyama* 3 \\ $*_{1}$ Premium Agency Inc. $\quad *_{2}$ Iwate University $\quad *_{3}$ Tokyo Polytechnic University \\ E-mail: konno@cis.iwate-u.ac.jp
}

アブストラクト

3 次元モデルの軽量化手法は, 肥大化する 3 次元形状の冗長性を削減し, 樣々なアプリケーションに適用可能な, 基本 的で重要な技術である．3 次元モデルの特徴を保存しながら，データを軽量化するためのアルゴリズムとして，QEM 手法があげられる．QEM 手法は，頂点を縮退した後の詳細さと軽量化速度の間で，最も良いバランスを持つアルゴ リズムのひとつである．しかし，QEM 手法は，一度にひとつの稜線しか削除できない逐次的なアルゴリズムである ため, 膨大な 3 次元モデルの軽量化には時間がかかる.PC クラスタは, メモリ分散型の計算環境として一般に用い られており，複数の PC を束ねることで, 計算資源を拡大することができる. 本論文では, QEM 手法を PC クラス 夕環境で動作させるための分散化手法について提案する．PC クラスタを利用することで, 安価なシステムにより 3 次元モデルの特徴を維持しながら，高速に軽量化することが可能となる .

\begin{abstract}
Simplification algorithm of 3D model is basic, important technology that can reduce the redundancy of the expanding 3D shape data, and that can apply to various applications. The QEM method is given as an algorithm to simplify data while preserving the feature of 3D model. The QEM method is one of the algorithms with the best balance between details and the simplification speed after the vertex is degenerated. However, because the QEM method is a successive algorithm that can delete only one edge at a time, it takes time for simplification of the huge 3D models. PC cluster is one of the environment that can enlarge computational resources with uniting many PCs. It is constructed easily and used generally. In this paper, it proposes the method made parallel by extending the QEM method, and using the PC cluster. With the PC cluster constructed by typical windows PCs, simplification high-speed by this method becomes possible while maintaining the feature of 3D model.
\end{abstract}

キーワード : 3 次元モデル, PC クラスタ,データ軽量化, QEM 手法

Keywords : 3D Model, PC Cluster, Simplification, QEM Method

\section{1 はじめに}

デジタルエンジニアリング技術の発展により，3 次元 モデルは, 設計，製造だけでなく企画，営業，広報など の多くの部署で活用されている.しかし, 元になる 3 次 元モデルのデータ量は，年を追うごとに巨大化し，モデ リングや解析などのための計算量やメモリ使用量なども 増加の一途をたどっている.このような背景で, 3 次元 モデルの軽量化手法は，肥大化する 3 次元形状の冗長性 を削減し，樣々なアプリケーションに適用可能な，基本 的で重要な技術となっている .
3 次元モデルの特徽を保存しながら , データを軽量化 するためのアルゴリズムとして，QEM 手法 [1] があげ られる．QEM 手法は，頂点を縮退した後の詳細さと軽 量化速度の間で, 最も良いバランスを持つアルゴリズム のひとつである $[2]$ ．しかし，QEM 手法は ,一度にひと つの稜線しか削除できない逐次的なアルゴリズムである ため，膨大な 3 次元モデルの軽量化には時間がかかる． 3 次元モデルを有効に活用するためには, 膨大なデータ 量の 3 次元モデルに対する処理をストレスなく害行する ことが必要であり，このようなニーズに対応するための ひとつの解決策として，PC クラスタを利用することが あげられる $[3]$. 
$\mathrm{PC}$ クラスタは, 複数の $\mathrm{PC}$ をネットワークで結合し たシステムである．膨大な処理を，各 PC へ分散化する ことによって，各 PC の負荷を低減し処理を高速化する ことが可能である.例えば Hashimoto らは， 3 次元モデ ルを描画するために，PC クラスタを利用し，高解像度な 画像を生成する手法を提案している $[4]$ 。また，Wagner らは，巨大なモデルをレンダリングするために，PC ク ラスタを利用し，高解像度な画像をレンダリングするシ ステムを提案している $[5]$ ．また，著者らは，3 次元モ デル間の衝突判定を PC クラスタを利用して高速に実現 する手法について提案している $[6]$.このようにPCク ラスタを利用した画像処理や 3 次元形状処理に関する提 案はいくつかなされているが， 3 次元モデルを高速に軽 量化するための手法はほとんどない .

El-Sana らは，3 次元モデルの軽量化を並列処理する ための手法について提案している $[7]$. しかし彼らの手 法は, 複数 CPU を持つ共有メモリ型の計算機で害行 することを想定している .このような計算機は高価であ り，CPU 数などの計算資源を自由に拡張することは難 しい.

本論文では，QEM 手法を PC クラスタ環境で動作さ せるための分散化手法について提案する . 本手法では , 処理コストの高い軽量化処理を, 複数台のサーバに分散 することにより，処理時間を短縮することが可能となる． また本研究で用いる PC クラスタは, 通常のネットワー ク環境に接続された安価な Windows PC の集合である. 既存の計算機環境を光のままクラスタ化することができ るため, 計算問題の複雑さと 3 次元モデルの規模，ある いは PC の遊休度に応じて動的に PC を結合して，クラ スタ化することができる利点がある．以降では，PCク ラスタを構成する PC をサーバと呼ぶ .

\section{2 関連研究}

\subsection{QEM 手法}

Garland と Heckbert が考案した QEM 手法 [1] は， 頂点縮退アルゴリズムの一つである．QEM 手法は，軽 量化を実行した後の詳細さと軽量化スピードの間で最も 良いバランスを持つアルゴリズムの一つである $[2]$.

QEM 手法の概要は以下のようになる .

-QEM 手法を適用したい, 棱線の両端点を頂点ぺ アとして登録

- 登録した頂点を共有するポリゴンから $4 \times 4$ 行列 $Q$ を計算

- 行列 $Q$ を利用して, 全てのペアのコストを求め, コストの小さい順にソート

・頂点ペア $(\mathbf{V} 1 ， \mathbf{V} 2)$ の最適な縮退目標 $\mathbf{V}$ を計算

・最小コストの頂点ペアを削除し，1 点に縮退した
頂点で置換

・置換された縮退頂点の周りのすべてのペアのコス 卜を更新

QEM 手法では, 上記の手順に従い頂点の縮退を繰り返 し行い, 削除するポリゴン数が一定の割合に達したとこ ろで, 軽量化処理を終了する.

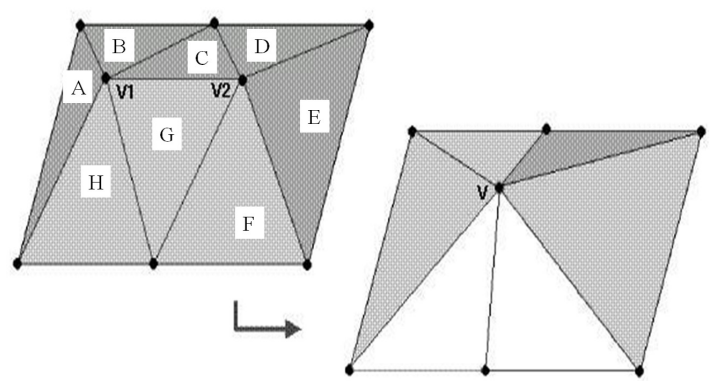

图 1 QEM 手法アルゴリズム

行列 $Q$ の要素は, 頂点の周りのすべての平面の方程式 から計算する . 平面の方程式を，

$$
a x+b y+c z+d=0 \quad\left(a^{2}+b^{2}+c^{2}=1\right)
$$

と定義すると，行列 $Q$ は, 式(1)のように表される .

$$
Q=\sum_{P \in \text { planes }(v)} K_{p}
$$

ただし，

$$
K_{p}=\left[\begin{array}{cccc}
a^{2} & a b & a c & a d \\
a b & b^{2} & b c & b d \\
a c & b c & c^{2} & c d \\
a d & b d & c d & d^{2}
\end{array}\right]
$$

である . また $\operatorname{planes}(v)$ は, 頂点 $v$ の周りのすべての平 面を表す。

図 1 に示すように，注目する頂点を $\mathrm{V} 1$ とすると，頂 点 $\mathrm{V} 1$ の周りの平面は $\mathrm{A}, \mathrm{B}, \mathrm{C}, \mathrm{G}, \mathrm{H}$ である .この 5 つの平面の方程式の係数から得られた值を，頂点 $\mathrm{V} 1$ に おける行列 $Q$ の要素とする .

また，縮退目標 $\mathbf{V}$ とは，ペア $(\mathbf{V} 1 ， \mathbf{V} 2)$ が縮退した ときに移動する頂点のことで， $(\mathbf{V} 1 ， \mathbf{V} 2) \rightarrow \mathbf{V}$ と表わさ れる、縮退目標 $\mathbf{V}$ における誤差は，誤差評価式を次の ように定義して計算される。

$$
\Delta(\mathbf{V})=\mathbf{V}^{T} Q \mathbf{V}
$$

ただし，

$$
\mathbf{V}=\left[\begin{array}{llll}
V_{x} & V_{y} & V_{z} & 1
\end{array}\right]^{T}
$$

である .

ここで， $Q$ は頂点ペアの持つ行列 $Q_{i}$ の和である . 例 えば，(V1，V2) $\rightarrow \mathbf{V}$ では， $Q=Q_{1}+Q_{2}$ となる.誤差 
評価式は $\mathbf{V}$ の二次関数であるので, $\Delta(\mathbf{V})$ を偏微分し て縮退目標 $\mathbf{V}$ を求める.

また， 2 頂点の間の稜線を縮退するかどうかを評価 するときのコストとして $\Delta(\mathbf{V})$ の值を利用する．例え ば， $(\mathbf{V} 1 ， \mathbf{V} 2)$ の誤差評価式 $\Delta(\mathbf{V})$ の值を，頂点ペア $(\mathbf{V} 1, \mathbf{V} 2)$ の稜線のコスト值とする . 最小コストの頂点 ペアを縮退することは, 形状の変化が最小で頂点縮退が 可能であることを意味する .

$\mathrm{QEM}$ 手法を $\mathrm{PC}$ クラスタへ適用するとき，各サーバ に割り当てられたポリゴンを分散して読み込み，各サー バが個別に QEM 手法を行う方法が考えられる.しか し，サーバで行われる軽量化の終了条件を，どのように 決定するかが不明確である，といった問題がある，従来 の QEM 手法では, 削除するポリゴン数が一定の割合に 達したところで処理を終了していた .しかし , 分散化を 行なった場合，各サーバに同一のポリゴン数削減割合を 終了条件として与えると, 各サーバから得られたポリゴ ンを統合後, 軽量化された形状の幾何学的整合性が崩れ る可能性がある．なぜなら，形状全体からすれば，ある サーバに割り当てられた領域は終了条件として与えられ た削減割合よりも少ない削減数とするのが妥当であるか もしれないし，また別のサーバへ割り当てられた領域は， 削減割合よりも多くのポリゴンを削減する必要があるか もしれないからである.

また，QEM 手法は，稜線の縮退を行なうとき，形状 全体から 1 度に 1 つの稜線しか縮退できないという制 約がある. 分散化を行ったとき，あるサーバへ割り当て られた領域の中で, 1 つの稜線が縮退可能であると判断 されても，形状全体からすれば，弚の稜線が最優先で縮 退されるべき稜線であるとは限らない，弚のため，どの サーバが持っている領域の稜線を縮退するかを決定しな がら， 1 本ずつ稜線を縮退していく方法では，PC クラ スタによる分散化の効果は，まったく得られない，我々 は, この点に着目し, 各サーバが独立して棱線を縮退で きる基準を新たに設け，各サーバが持つ部分形状を個別 に軽量化できるように，QEM 手法を PC クラスタ環境 に適用させる .

\section{2 並列形状軽量化手法}

El-Sana らは, 並列環境におけるポリゴンの軽量化手 法を提案している [7] . El-Sana らの手法は, 共有メモ リ型のマルチプロセッサマシンにおいて , 視点パラメー タに依存してポリゴンを軽量化する手法である.

El-Sana らの軽量化手法の概要は以下のようになる.

1. ポリゴンをオクトリに従って空間分割する . 分割 された部分空間をセルと呼ぶ .

2. セルに含まれる頂点数の多い順に, 各セルをソー トし，セルのリストを作っておく .
3.リストからセルをひとつ取り出し, セル内のポ リゴンに関して棱線ヒープを構筑し, セル優先度 キューに追加する．この処理は，空いている $\mathrm{CPU}$ に次々割り当てられる.

4. セル優先度キューから優先順位の高いセルを取り 出し，空いている $\mathrm{CPU}$ へ割り当てる．弚の $\mathrm{CPU}$ では,セルか持つ稜線ヒープに登録されている稜 線を対象に軽量化 (稜線削除)を行なう。一定の 部分空間の処理が修了したら，元の親の部分空間 をひとつのセルと見なして , 棱線ヒープを再構筑 し，セル優先度キューへ追加する．このとき，子 空間を表すセルは優先度キューから削除する．

5. キューを更新する.

各セルでは, セル内において , 棱線の長さが短いもの から，棱線削除を行なう．ただし，次の 2 つの条件に合 う場合のみ，稜線の削除処理は行なわれる。

1. 削除された 2 つの頂点のどちらかに隣接する三角 形において,削除の前後の三角形の法線の違いが， ユーザに指定された閾値の範囲内である

2. 削除された 2 つの頂点のどちらかに隣接する三角 形において，三角形のクォリティが, ユーザが決 定した閾值を下回っていない

三角形のクォリティは, 三角形の面積 $a$ および, 各辺の 長さ $l_{0}, l_{1}, l_{2}$ に基づいた式 (3) で定量化する .

$$
\text { Quality }=\frac{4 \sqrt{3} a}{l_{0}^{2}+l_{1}^{2}+l_{2}^{2}}
$$

El-Sana らの手法は, 複数の CPU を持つメモリ共有 型の計算機で実行することを想定している．メモリを 共有すると, 複数の CPU は, 同一のメモリ空間にアク セスすることが可能なので，通信や同期などのオーバー ヘッドは少ない．しかし，このような計算機は高価であ り，CPU の数などを自由に拡張することは難しい .

彼らの手法を, 分散メモリ型の PC クラスタ環境で実 現する場合には，共有メモリー上に保存されているセル 優先度キューと軽量化対象の形状モデルを, 何らかの方 法で分散化する必要がある. 分散メモリ型の PC クラス タでは, 通信量と回数を少なくすることが, 並列化効率 を上げるための方策のひとつであり，乥の点を考慮する 必要がある . 軽量化は PC クラスタで実行するので, 各 サーバに形状モデルを持たせると仮定する．また，空い ているサーバを管理するのはクライアントなので, セル 優先度キューをクライアントに持たせ , 空いているサー バにどのセルを処理するのかを指示すると仮定する . こ のようなシステムにおける問題点は次のようになる .

・セルに含まれる形状を軽量化するサーバは, クラ イアントが選択するので, 異なるサーバが害行し 
た軽量化結果を，他のサーバに反映して，形状モ デルの整合性を取る必要がある．たとえば，子の 部分空間を表すセルに含まれる形状を軽量化し たサーバと，弚の子の親の部分空間を表すセルに 含まれる形状を軽量化するサーバが異なる場合に は, 複数のサーバ間で形状モデルの整合性を取る 必要がある . PC クラスタを利用するとき, 形状 モデルの整合性をとりながら，軽量化するのはコ ストがかかり，効率もよくない．

・ セル優先度キューの更新は, 各サーバでセルの処 理が終了するごとに排他制御しながら行う必要が ある.セル数が多くなると，同期や通信コストが 多くなり，効率が低下する．

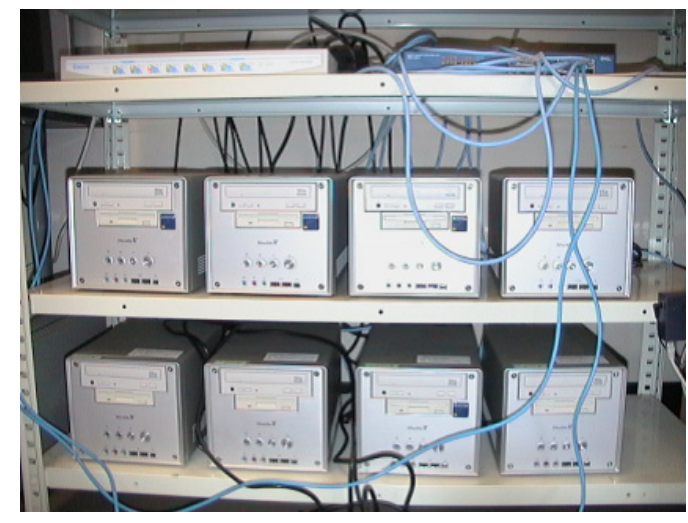

図 2 PC クラスタ

\section{3 次元モデル軽量化手法の分散化}

\section{1 概要}

本手法では ,一般の Windows PC をギガビットネッ トワークで結合したメモリ分散型のクラスタシステムを 利用する . 図 2 に本研究で利用している PC クラスタを 示す . この図では， 8 台の PC をギガビットネットワー クに接続している。

2.1 節で述べたように，QEM 手法は,削減したいポリ ゴン数あるいは, 削減割合を指定して, 削除することに よる形状変化のもつとも少ない棱線を縮退してポリゴン を削除する手法である．縮退する稜線は，ポリゴンモデ ルの局所的な幾何形状に基づいて , 計算されたコスト值 により決定される．したがって，ポリゴンを部分形状に 分割し各サーバに分散した場合, 部分形状の境界以外は, 各棱線のコストは分割前と変わらない，乥こで各サーバ は, 部分形状の境界に接触しているポリゴン以外のポリ ゴンに属する稜線を対象として，軽量化処理を実行すれ ば，並列に軽量化することが可能である．各サーバでの 軽量化の過程では, 部分形状の境界は軽量化対象ではな いため，境界稜線は变更されない，すなわち，ほかのク
ラスタで処理されている部分形状には影響しない．ク ライアントが各サーバの軽量化結果を統合化した後, 部 分形状の境界稜線を対象としてさらに軽量化を実行すれ ば，形状全体の軽量化が可能である．

部分形状に対する軽量化処理は，各サーバで独立に実 行できるので, サーバ間で形状モデルの整合性を取る必 要はない，また，各サーバで害行される軽量化処理では， 毎回クライアントに実行結果を送信する必要はないた め，通信回数も少なくてすむ．以上のような手法で軽量 化することによって，2.2 節で述べた問題を解決できる．

弚のためには，逐次的に縮退稜線を決定する QEM 手 法を PC クラスタ環境に適用させる必要がある．乥こ で本手法では，各サーバか計算した棱線のコストをクラ イアントで集約し，削減割合を考慮した，コストの閾値 を各サーバへ指示する方法を新たに導入する．最小コス トでなくともコストが閾値以下の稜線であれば, 削除す ることができることとする .これにより各サーバでは， コストの閾値に基づき，QEM 手法で棱線縮退を行なう ことが可能となるため，ポリゴン数に依存せずに独立し て軽量化を実行することができるようになる．軽量化の 終了条件を閾値で指定することで, 各サーバでは並列に QEM 手法を実行することができるため, メモリ分散型 の PC クラスタ環境において, 分散化手法を実現するこ とが可能となる．また，設定した閾値までなら各サーバ で別々に削除することができることから，クライアント との通信量も削減できる.

本手法では, コストの閾値を軽量化前の形状の全コス トとユーザーが指定したポリゴンの削減割合から自動 的に決定し，兴の值を各サーバに指定する．各サーバで は，QEM 手法を適用中に，最小コスト值と与えられた コストの閾値を比較し，最小コスト值が閾値よりも大き くなったところで, 軽量化を終了する. 本手法は, クラ イアントが各サーバに分散されている稜線のコストを集 約し，適切なコストの閾値を決定する．したがって，ク ライアントが保存できる稜線数以上の, 膨大なモデルは 処理が困難である，といった制約は残される．

\section{2 分散処理の流れ}

図 3 に，本手法による 3 次元形状の軽量化の流れを示 す . 図中の番号が，以下の処理の番号と対応する . ただ し，3 次元形状を分散化するときは，事前に形状を領域 分けしておく. 領域分けの詳細は 3.3 節で述べる .

クライアントは , すべてのサーバへ , データファ イルとポリゴンの領域を指定し読み込みを命令 する．

サーバは指定された領域についてのデータを読み 込む。

（3）クライアントは, すべてのサーバへ, 読み込んだ 
領域のすべてのコストの計算を命令する .

（4） サーバは, 各頂点の行列 $Q$ 及び頂点ペアのコスト を計算し, クライアントの要求により保存してい るコスト值を渡す．

（5）クライアントは, ユーザか指定したポリゴン削減 割合を基に，サーバから収集した全コスト值を参 照して閾值を決定する。

（6） クライアントは, すべてのサーバへ, 閾值を終了 条件として指定し，QEM 手法を適用するように 命令する .

（7） サーバは, 閾值と現在の最小コスト值を比較しな がら，終了条件に達するまで, 繰り返し QEM 手 法を適用する .

（8）クライアントは,すべてのサーバへ,QEM 手法を 適用した回数として縮退した稜線数を要求する. サーバはクライアントの要求通り, 棱線数をクラ イアントへ渡す。

（9）クライアントは, すべてのサーバへ, QEM 手法 を適用した結果を要求する.サーバはクライアン 卜の要求通り,軽量化結果をクライアントへ渡す．

（10）クライアントは, 受け取った稜線数から削減され たポリゴン数を計算し，ユーザが指定した削減割 合にどの程度近づいたかを算出する．

(11) クライアントは, ユーザが指定した削減割合に対 して,どの程度削減すればよいのかを考慮しなが ら，閾值を再設定する。

(12) 手順 6 から 11 を, 削減割合と全体のポリゴン数 及び境界上のポリゴン数を考慮した割合になるま で繰り返す。

（13）クライアントは, すべてのサーバの結果を元に軽 量化されたデータを統合化する .

（14）統合化後に，1 台のサーバを使用し，ユーザが指 定した削減割合に達するまで, 従来の QEM 手法 を適用する。

\section{3 領域分け}

3 次元形状を各サーバへどのように割り当てるのかは， 重要な課題である . 計算オーバーヘッドを少なくし，高 速に処理するためには，各サーバにおける計算量をでき るだけ均一にすることが望ましいが，あらゆる形状に対 して，計算量を均一にすることは困難な課題である．

本研究では, 各サーバが処理するポリゴン数が均一の ときに, 各サーバで削減されるポリゴン数が, 極端にア ンバランスにならないような, ポリゴンモデルを前提と する. 乥こで本手法では, 各領域のポリゴン数がほぼ均 一になるように，領域成長法の概念を用いた単純な方法 で領域分けを行なう．具体的には，基準面をユーザーが 指定し，弚の面に隣接する面を同一のグループとなるよ

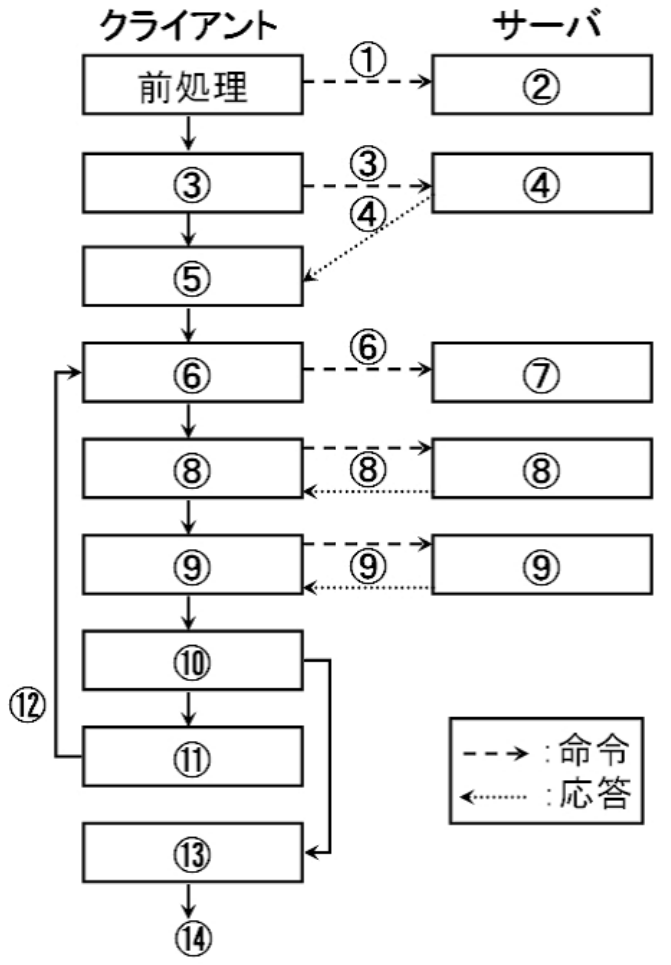

図 3 分散処理の流れ

うに追加する. 兴のグループに属する面数が一定数に達 するまで，処理を継続する.図 4(b) は，図 4(a) のポリ ゴンモデルをポリゴン数が均一になるように 8 つの領域 八領域わけした例である .

ポリゴンモデルの一部が複雑な場合や，ポリゴンの詳 細さが偏った場合には, よりよい領域分割の手法が必要 である . 適切な分割手法は, 今後の課題である .

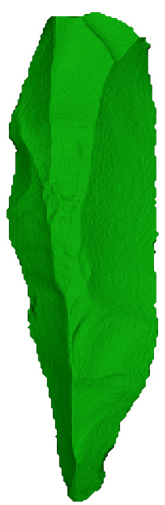

(a)

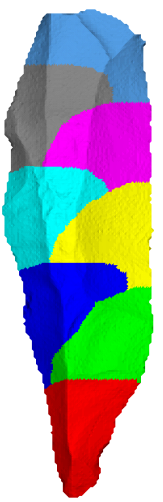

(b)

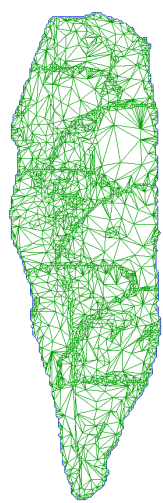

(c)

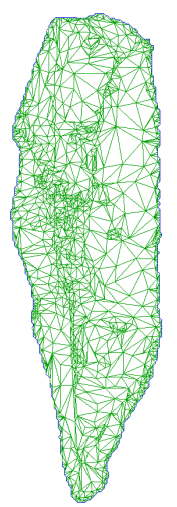

(d)
図 4 処理の樣子 (石器) (a) 元のポリゴンモデル （b) 領域分け例 (c) 1 パス目の軽量化後 (d)2 パス目 の軽量化後 


\subsection{QEM 手法の適用}

3.3 節で述べたように，3 次元形状を領域分けした後， サーバでは, 個別に QEM 手法を適用する.ある閾值に 達するまでサーバ個別に QEM 手法を適用することは， メモリ分散型の環境においては, クライアントとサーバ 間の通信量を少なくすることができるため，重要である． 通信量を削減するため，本手法では，領域分けされた部 分ポリゴンの内側の稜線は, 各サーバで軽量化を行い， 部分ポリゴンの境界線は, クライアントが軽量化結果を 統合後に, 1 台のサーバて軽量化を行う．

サーバで軽量化された 3 次元モデルを, クライアント が統合化する際に，領域間の境界が一致していないと， 領域間を近似的に接合する必要が生じる．領域間を近似 接合するためには，各領域を接合するための共通の境界 線を近似手法により算出しなければならないため，処理 が複雑になる。また，軽量化手法とは別に，形状を近似

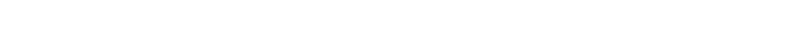
分ポリゴンの境界線を別途処理することで, 上記の問題 点も解決できる .

部分ポリゴンの境界線と接触するポリゴンは, 各サー バでの軽量化結果となるポリゴンを統合化後に，1台の サーバで再度 QEM 手法を実行する .このときには，本 論文で提案する，修了条件となる閾値を与えるのではな くて, 従来の QEM 手法 [1] を用いて, 削減割合に達す るまでポリゴンを削減する．これによって，領域の境界 曲線に対しても，軽量化処理が適用されることになる。 統合化の詳細は，3.6 節で述べる．

本手法では，サーバごとの軽量化を 1 パス目，統合化 後に 1 台のサーバでもう一度軽量化する処理を 2 パス目 とする . 図 4(c) は，(b) に示す 3 次元形状を軽量化した 例である . (c) を見るとわかるように, 1 パス目では, 領 域の境界付近のポリゴンは軽量化されていない . (d) に 示すように， 2 パス目では，領域の境界付近のポリゴン についても軽量化されるため, 全体的に 3 次元モデルが 軽量化されていることがわかる .

\section{5 コストの閾値の決定}

本手法で導入するコストの閾値とは，QEM 手法を適 用するときの終了条件である.しかし，コストの閾值は， 削除可能な稜線の周りにある平面形状から算出されたコ ストによって決められるため，棱線のコストを計算する までは閾値を決定することは難しい，また，形状によっ てコストや关の閾值は全く異なるため, 削減割合を考慮 し試行錯誤しながら閾値を指定しないと，最適な閾値を 得ることは難しい.よって，手動によりコストの閾値を 決めることは，困難である .

そこで本手法では, ユーザがポリゴンをどのくらい

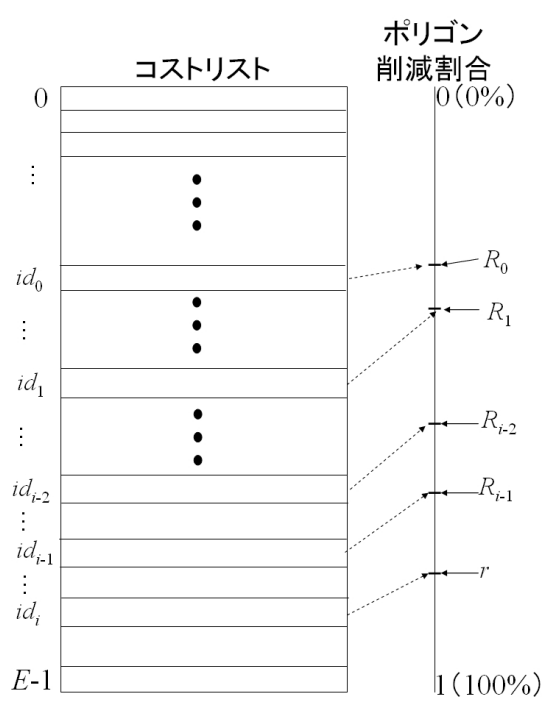

図 5 閾値決定の概念図

削減したいかを指定するだけで，自動的にコストから 最適な閾值を決定する．図 5 は，閾値決定の概念を示 す．まず初めに，各サーバへ割り当てられた領域に含ま れる稜線のコストを, 各サーバに計算させ , クライアン 卜は形状のすべてのコストを昇順にソートしたリスト として持つ.ユーザが指定したポリゴンの削減割合を $r(0<r<1)$ として，コストと削減割合を対応させる． 一般に, 削減割合 $r$ とコストリストの $i d_{i}$ が線形に対応 するわけではないので，あるコスト值を与えたときの実 際の削減割合から，最終的な削減割合 $r$ を達成するため のコストを推測する . 具体的には, 直前と光の前の削減 割合 $R_{i-1}, R_{i-2}$ と， $R_{i-1}, R_{i-2}$ を達成したときのコス 卜を決定したコストリストのインデックス $i d_{i-1}, i d_{i-2}$ から削減割合の差分 $\left(R_{i-1}-R_{i-2}\right)$ とインデックスの差 分 $\left(i d_{i-1}-i d_{i-2}\right)$ か線形に変化すると仮定して, コスト 值の位置 $i d_{i}$ を決定する.

リストに登録されている稜線数を $E$ としたときに,式 (4) に示す位置 $i d_{0}$ にあるコスト值を，コストの閾値の 初期値とする .

$$
i d_{0}=E * r / 2
$$

次のコスト值を決定するためのリストの位置を決定する ためには, 直前の 2 回分の削減割合の差分とコストリス 卜を決定した $i d$ の比を必要とする. 光のため $i d_{1}$ を, 式 (5) から暫定的に決定する .

$$
i d_{1}=i d_{0}+E * C_{1}
$$

本研究では, 経験的に定数 $C_{1}=0.002$ とする.クラ イアントは, サーバが $i-2$ 回目と $i-1$ 回目に軽量化 した形状の削減割合 $R_{i-2}, R_{i-1}$ と，弚のとき使用した コスト值を決定するためのリストの位置 $i d_{i-2}, i d_{i-1}$ よ り, $\left(R_{i-1}-R_{i-2}\right)$ と $\left(i d_{i-1}-i d_{i-2}\right)$ の変化が線形で あると仮定し， $i$ 回目のコスト值を決定するためのリス 
トの位置 $i d_{i}(i \geq 2)$ を, 式 (6) から決定する .

$$
i d_{i}=i d_{i-1}+E *\left(\frac{\left(R_{i-1}-R_{i-2}\right)}{\left(i d_{i-1}-i d_{i-2}\right)} *\left(r-R_{i-1}\right)\right)
$$

2 パス目の処理で, 境界部分の棱線が十分に軽量化され るように，ユーザか指定した削減割合よりも低い削減割 合で 1 パス目の処理を終了する．具体的には， $i d_{i} に$ にお けるコスト值をサーバへ指定したときの実際の 削減割 合 $R_{i}$ が,式 $(7)$ を満たすまで,式 (6) を用いて閾值を再 設定し軽量化を続ける.

$$
R_{i} \geq r-\frac{n}{E} * C_{2}
$$

ただし， $n$ は, サーバ 1 台あたりのポリゴン数とする. 2 パス目の処理でどの程度軽量化するかは，定数 $C_{2}$ の 值で微調整することができる.本研究では， $C_{2}=1.0$ と している. $C_{2}>1$ とすることによって，1 パス目で削 減されるポリゴン数は減少し, $C_{2}<1$ のときには, 1 パ ス目で削減されるポリゴン数は増加する.

ユーザは従来と同樣に QEM 手法の削減割合を指定 し,システム側でコストの閾値に置換することで, PC ク ラスタで軽量化を並列処理することが可能となる．ユー ザが, 削減された後のモデルの面数を指定したい場合は， 全体の面数と削減された後のモデルの面数から, 削減割 合を算出すればよい .

\section{6 統合化}

統合化とは, 各サーバで行なった軽量化処理のすべて の結果をクライアントへ集約することである . 統合化に 必要な情報は, 各サーバの軽量化後のポリゴンデータで ある. 本手法では，クライアントが結果形状を得る方法 として，Hoppe が提案した Progressive Mesh [9] の 考え方を用いる.具体的には，各サーバが，軽量化処理 を適用する際に使用した，頂点ペア $(\mathbf{V} 1 ， \mathbf{V} 2)$ の頂点番 号と頂点 $\mathbf{V} 1$ から縮退目標 $\mathbf{V}$ へ向かうベクトルの情報 を，形状へ適用した順に並べた変形操作履歴を用いる。 クライアントは, 変形操作履歴のみを受け取り, 弚れに 従って变形操作を形状に適用することで, 形状を統合化 する .

大量のポリゴンを削除した結果，面数が少なくなれば 変形操作履歴よりも結果のポリゴンデータのほうがデー 夕量が少なくなることも考えられる，弚の場合には，ポ リゴンデータを直接転送してもよい．

\section{4 実験}

まず最初に，3.4 節で述べた 2 パス方式での軽量化手 法による軽量化結果の妥当性について検証する．1 台で 軽量化した軽量化結果と, サーバ台数を 2 台から 8 台 まで変化させたときの軽量化結果を光れ比較した .
本手法は, サーバが 1 台の場合は, 1 パス目をスキップ して 2 パス目のみを弚のサーバで実行する．すなわち， サーバ台数が 1 台の場合は, 従来の QEM 手法による軽 量化を実行するので，弚の結果を基準にして形状を比較 する．比較に利用したツールは，Metro [8] である．図 6 に示す馬モデルと，図 7 に示す船モデルに対して, 削 減割合を $90 ， 95 ， 99 \%$ に指定したときの軽量化モ デルを，Metro を利用して評価した結果が表 1 である 数値は, 形状の境界箱の大きさに対する最大距離の割合 である．表を見るとわかるように，各削減率において， サーバ台数の変化が形状の変化に与える割合はほとんど 変わらない，すなわち結果形状の品質は，領域分けにほ とんど影響されないことがわかる．このことから，提案 手法である 2 パスで実行する場合と従来の QEM 手法 との違いは非常に少ないことが分かる.

表 1 サーバ1台で軽量化した結果に対する最大距離の割合

\begin{tabular}{|c||c|c|c|}
\hline サーバ数 & 2 & 4 & 8 \\
\hline 馬 $(90 \%)$ & $0.0403 \%$ & $0.0446 \%$ & $0.0448 \%$ \\
\hline 馬 $(95 \%)$ & $0.0678 \%$ & $0.0819 \%$ & $0.0724 \%$ \\
\hline 馬 $(99 \%)$ & $0.3147 \%$ & $0.3121 \%$ & $0.3217 \%$ \\
\hline 船 $(90 \%)$ & $0.0830 \%$ & $0.0830 \%$ & $0.0561 \%$ \\
\hline 船 $(95 \%)$ & $0.0756 \%$ & $0.0756 \%$ & $0.1117 \%$ \\
\hline 船 $(99 \%)$ & $1.2885 \%$ & $0.3907 \%$ & $0.4668 \%$ \\
\hline
\end{tabular}

次に, サーバ台数を増加させたときの，速度を評価 する、実験に使用したサーバ PC は，CPU Pentium4 $3.0 \mathrm{GHz}$ ，メモリ1GBである.まず 3.3 節で述べた方法 により，形状に対して，サーバ台数分の領域分けを行な う．次に，部分領域を各サーバへ読み込み，本手法によ る軽量化を実施する.サーバ台数を 1 台から 8 台まで 変化させたときの, 軽量化時間と 1 台の実行時間との 速度比を示し, PC クラスタにより軽量化速度が向上し ていることを確認する．ただし，ポリゴンの削減割合は $90 \%$ に設定する .

表 2 に，図 4 に示した石器のデータに対する軽量化処 理時間を示す . ポリゴン数は 24,609 である. 軽量化時 間は，サーバが QEM 手法を適用していた時間である． 結果取得時間は, クライアントがサーバから変形操作履 歴を受け取るために要した時間である．統合化時間は， クライアントによる統合化の時間である . また, 軽量化 時間，結果取得時間及び統合化時間については，1 パス 目と 2 パス目及び光の合計となっている.上記 3 合計 は, 軽量化時間, 結果取得時間及び統合化時間の合計で ある. 速度比率はサーバ数が 1 台のときとの比較によ る，合計時間の倍率である．なお，サーバ台数が 1 台の とき, 1 パス目の時間が「一」になっているのは，領域を 分割していないため, 1 パス目を実行する必要がないか 
表 2 石器のデータの軽量化処理時間 (単位は秒)

\begin{tabular}{|r||c|c|c|c|}
\hline サーバ数 & 1 台 & 2 台 & 4 台 & 8 台 \\
\hline 1 パス目 & - & 3.204 & 1.798 & 1.046 \\
2 パス目 & 7.016 & 0.110 & 0.235 & 0.359 \\
\cline { 2 - 5 } 軽量化時間合計 & 7.016 & 3.314 & 2.033 & 1.405 \\
\hline 1 パス目 & - & 0.187 & 0.186 & 0.249 \\
2 パス目 & 0.140 & 0.015 & $0.000 *$ & 0.016 \\
\cline { 2 - 5 } 結果取得時間合計 & 0.140 & 0.202 & 0.186 & 0.265 \\
\hline 1 パス目 & - & 0.171 & 0.172 & 0.172 \\
2 パス目 & 0.172 & 0.016 & 0.031 & 0.047 \\
\cline { 2 - 5 } 統合化時間合計 & 0.172 & 0.187 & 0.203 & 0.219 \\
\hline 上記 3 合計 & 7.328 & 3.953 & 2.422 & 1.889 \\
\hline 速度比率 & 1.00 & 1.85 & 3.03 & 3.88 \\
\hline
\end{tabular}

らである．また，表中の $0.000 *$ は，計測時間が $1 / 1000$ 秒よりも短い時間であることを示す．

表 2 より, サーバ台数が 8 台のときは, 1 台のとき の約 3.9 倍に速くなっている.これは, サーバ数が増え ると軽量化時間は約 5.0 倍高速化できるが, 分散処理の オーバーヘッドにより，軽量化処理としては，約 3.9 倍 程度になるためと考えられる．また，サーバ数か増える と，徐々に分散化効率が落ちているが，形状を表わすポ リゴン数があまり多くないため, 軽量化処理時間が頭打 ちになってくるためであると考えられる .

図 4(c) は,領域を 8 つに分けPC クラスタに割り当て たときの, 1 パス目の軽量化処理後のワイヤーフレーム 表示である. 同樣に図 $4(\mathrm{~d})$ は, 2 パス目の軽量化処理後 のワイヤーフレーム表示である . 軽量化前の形状のポリ ゴン数が 24,609 であるのに対し，1 パス目の軽量化後で 4,031 に, 2 パス目の軽量化後で 2,459 に変化している

図 6(a)に,ポリゴン数 96,966 の馬のデータを示す また，図 6(b) は, 8 つに領域分けをした図である.この データについても同樣の実験を行なった結果が表 3 であ る.サーバ台数が 8 台の時は, 1 台の時の約 5.3 倍高速 化することができた . 軽量化時間だけに着目すると， 1 台のときと比較して 8 台のときは, 約 6.8 倍高速化され ている.ポリゴン数が多くなると，全体の処理時間に対 する結果取得時間と統合化時間の占める割合が少なくな るため，PC クラスタによる分散化効率が高まることが わかる .

図 6(c) は,図 6(a) に示した馬のデータの, 軽量化処理 前のワイヤーフレーム表示である . また図 $6(\mathrm{~d})$ は, 領域 を 8 つに分け PC クラスタに割り当てたときの, 1 パス 目の軽量化処理後のワイヤーフレーム表示である . 同樣 に図 6(e) は, 2 パス目の軽量化処理後のワイヤーフレー ム表示である. 軽量化前の形状のポリゴン数が 96,966 であったのに対し，1 パス目の軽量化後で 12,176 に，2 パス目の軽量化後で 9,696 に変化している.また図 $6(\mathrm{f})$
表 3 馬のデータの軽量化処理時間（単位は秒）

\begin{tabular}{|r||c|c|c|c|}
\hline サーバ数 & 1 台 & 2 台 & 4 台 & 8 台 \\
\hline 1 パス目 & - & 11.688 & 5.906 & 3.628 \\
2 パス目 & 29.859 & 0.469 & 0.844 & 0.781 \\
\cline { 2 - 5 } 軽量化時間合計 & 29.859 & 12.157 & 6.750 & 4.409 \\
\hline 1 パス目 & - & 0.703 & 0.672 & 0.748 \\
2 パス目 & 0.641 & $0.000 *$ & 0.015 & 0.031 \\
\cline { 2 - 5 } 結果取得時間合計 & 0.641 & 0.703 & 0.687 & 0.779 \\
\hline 1 パス目 & - & 0.562 & 0.547 & 0.547 \\
2 パス目 & 0.563 & 0.047 & 0.079 & 0.078 \\
\cline { 2 - 5 } 統合化時間合計 & 0.563 & 0.609 & 0.626 & 0.625 \\
\hline 上記 3 合計 & 31.063 & 13.469 & 8.063 & 5.813 \\
\hline 速度比率 & 1.00 & 2.31 & 3.85 & 5.34 \\
\hline
\end{tabular}

表 4 船のデータの軽量化処理時間（単位は秒)

\begin{tabular}{|r||c|c|c|c|}
\hline サーバ数 & 1 台 & 2 台 & 4 台 & 8 台 \\
\hline 1 パス目 & - & 28.892 & 12.579 & 6.750 \\
2 パス目 & 82.156 & 1.031 & 1.672 & 3.078 \\
\cline { 2 - 5 } 軽量化時間合計 & 82.156 & 29.923 & 14.251 & 9.828 \\
\hline 1 パス目 & & 1.311 & 1.328 & 1.312 \\
2 パス目 & 1.297 & 0.016 & 0.047 & 0.078 \\
\cline { 2 - 5 } 結果取得時間合計 & 1.297 & 1.327 & 1.375 & 1.390 \\
\hline 1 パス目 & - & 1.015 & 1.047 & 1.016 \\
2 パス目 & 1.094 & 0.078 & 0.078 & 0.110 \\
\cline { 2 - 5 } 統合化時間合計 & 1.094 & 1.093 & 1.125 & 1.126 \\
\hline 上記 3 合計 & 84.547 & 32.343 & 16.751 & 12.344 \\
\hline 速度比率 & 1.00 & 2.61 & 5.05 & 6.85 \\
\hline
\end{tabular}

は,図 6(e) に示した結果をポリゴンで表現したものであ る.図6(a) と比較してみても，見た目の変化はほとん ど無く，軽量化は成功している．

図 7(a)に，ポリゴン数 194,092 の船のデータを示す． 図 7(b) は, 船のデータを 8 つに領域分けをした図であ る.このデータについても同樣の実験を行なつた結果が 表 4 である .また ，この船のデータのポリゴンを Loop 細分割 [10] を 1 回実行して , ポリゴン数を 4 倍にした ポリゴン数 776,368 の船 (4 倍) のデータについて, 同樣 の実験を行なった結果が表 5 である．なお，船 (4 倍)の データの領域分けについては，船のデータのポリゴンを， 細分割したものであるため, 船のデータと同樣となって いる . 船のデータについては ,サーバ台数が 8 台のとき， 1 台のときの約 6.9 倍に高速化することができた . 船 (4 倍)のデータについては，約 18.2 倍高速化することがで き，特に軽量化時間だけに着目すると，サーバ台数が 1 台のときと比較して，約 22.0 倍高速化されている.サー 


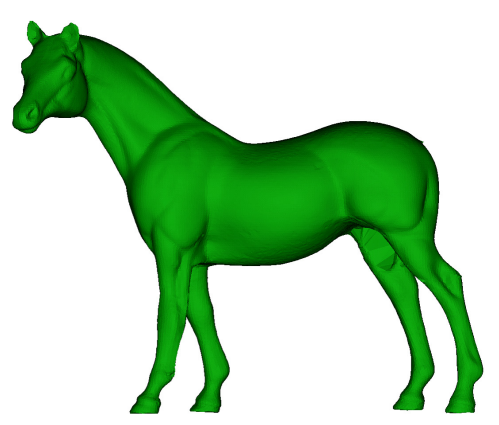

(a)

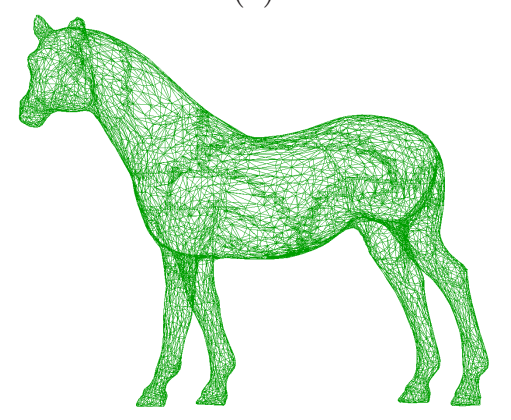

(d)

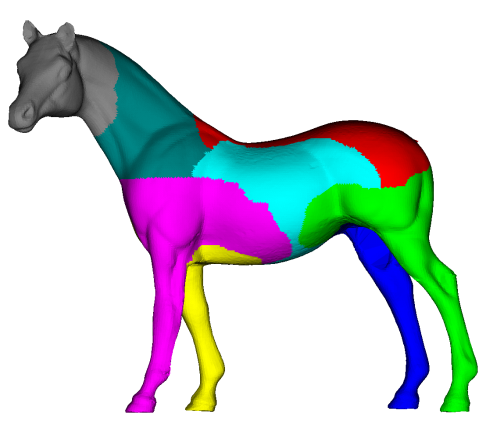

(b)

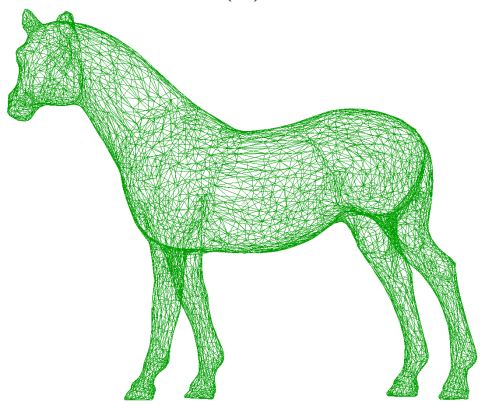

(e)

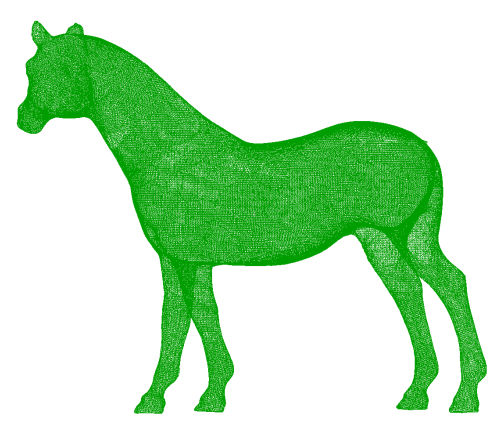

(c)

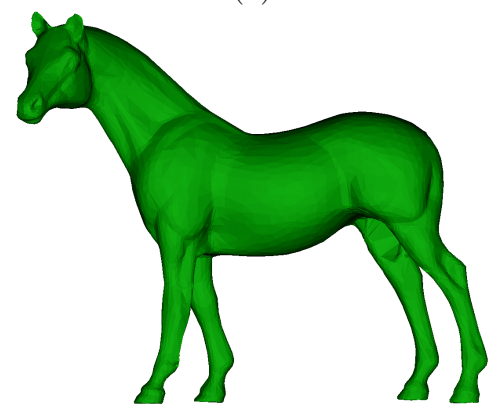

(f)

図 6 実験例 (馬) $\quad$ (a) 元のポリゴンモデル $\quad$ (b) 領域分け例 $\quad$ (c) 軽量化前の形状 $\quad$ (d)1 パス目の軽量化後の 形状 (e)2 パス目の軽量化後の形状 (f) 軽量化後のポリゴンモデル

表 5 船 (4 倍) のデータの軽量化処理時間 （単位は秒）

\begin{tabular}{|r||c|c|c|c|}
\hline サーバ数 & 1 台 & 2 台 & 4 台 & 8 台 \\
\hline 1 パス目 & - & 260.281 & 85.533 & 35.813 \\
2 パス目 & 978.125 & 3.859 & 5.922 & 8.547 \\
\cline { 2 - 5 } 軽量化時間合計 & 978.125 & 264.140 & 91.455 & 44.368 \\
\hline 1 パス目 & - & 5.313 & 5.342 & 5.515 \\
2 パス目 & 5.265 & 0.047 & 0.094 & 0.141 \\
\cline { 2 - 5 } 結果取得時間合計 & 5.265 & 5.360 & 5.436 & 5.656 \\
\hline 1 パス目 & - & 4.156 & 4.093 & 4.062 \\
2 パス目 & 4.250 & 0.094 & 0.125 & 0.172 \\
\cline { 2 - 5 } 統合化時間合計 & 4.250 & 4.250 & 4.218 & 4.234 \\
\hline 上記 3 合計 & 987.640 & 273.750 & 101.109 & 54.258 \\
\hline 速度比率 & 1.00 & 3.61 & 9.77 & 18.20 \\
\hline
\end{tabular}

バ台数が 4 台から 8 台に変化するときには, 速度は約 2 倍に高速化されているが, 2 台から 4 台, あるいは 1 台 から 2 台の場合には , 2 倍以上の高速化が実現されてい る.これは, ポリゴン数が多い場合には, 1 台のサーバ で利用できるメモリ量の制限などによってメモリスワッ プなどのオーバーヘッドが生じるため, 処理時間が長く なると考えられる．

船のデータの軽量化処理の樣子について, 図 $7(\mathrm{c}),(\mathrm{d}),(\mathrm{e})$ にワイヤーフレーム表示で示す . 船のデー タについては, 軽量化前の形状のポリゴン数が 194,092 であるのに対し，1 パス目の軽量化後で 25,280 に，2 パス目の軽量化後で 19,408 に変化している.また，船

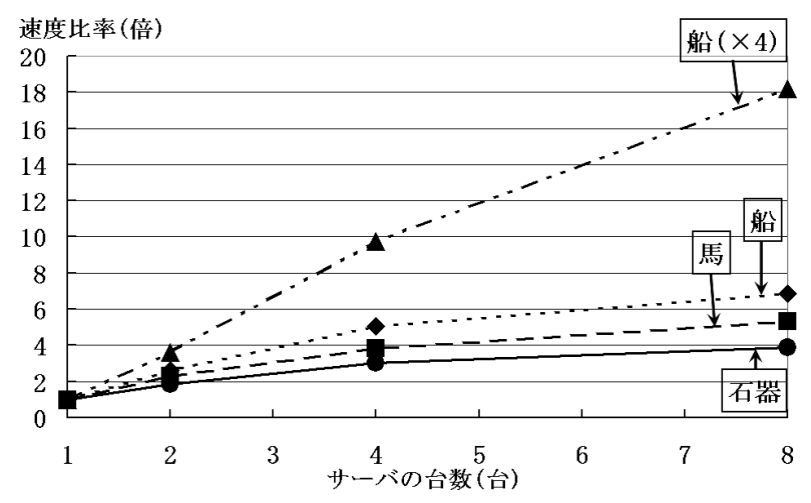

図 8 各実験データの速度比率

(4 倍) のデータについては, 軽量化前の形状のポリゴ ン数が 776,368 であるのに対し，1 パス目の軽量化後で 103,200 に, 2 パス目の軽量化後で 77,636 に変化してい る.また図 $7(\mathrm{f})$ は, 図 $7(\mathrm{e})$ に示した結果をポリゴンで 表現したものである .この例に関しても，軽量化結果の 形状は良好である。

図 8 に, 石器, 馬, 船, 船 (4 倍) のデータについて,サー バ台数と速度比率に関するグラフを示す.ポリゴン数が 多い形状ほど，グラフはより線形に推移し，分散化によ る処理効率が高まることがわかる．また，ポリゴン数が 多くなったとき，サーバの台数を増やすことによって， 軽量化処理の効率が高まることも予想できる . 以上のこ とから，本軽量化手法の有効性が確認できた . 


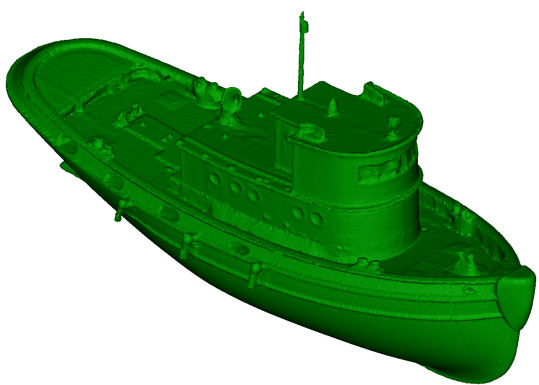

(a)

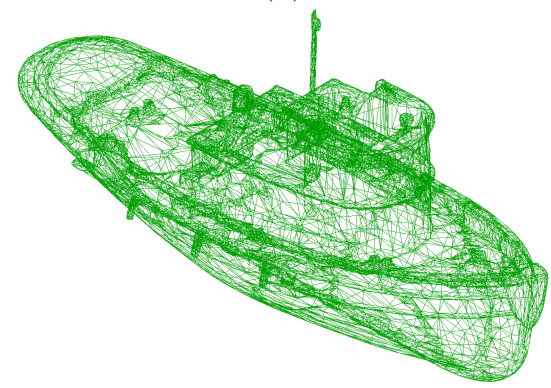

(d)

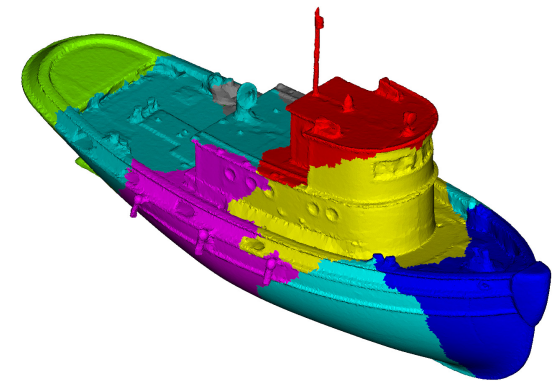

(b)

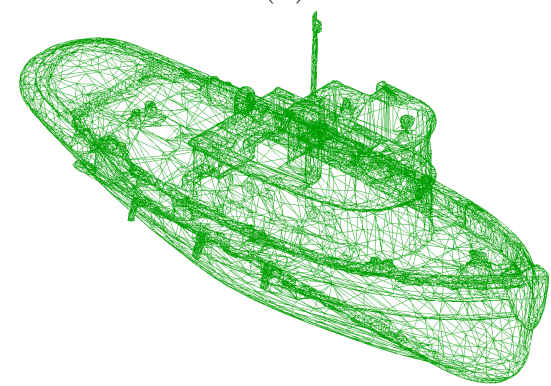

(e)

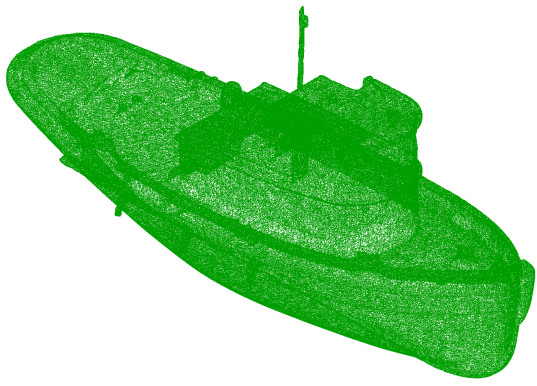

(c)

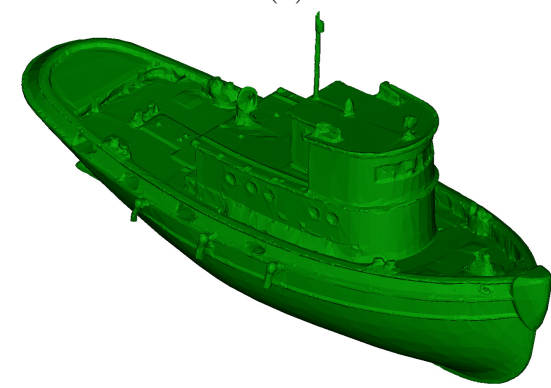

(f)

図 7 実験例 (船) $\quad$ (a) 元のポリゴンモデル $\quad$ (b) 領域分け例 $\quad$ (c) 軽量化前の形状 $\quad$ (d)1 パス目の軽量化後の 形状 (e)2 パス目の軽量化後の形状（f) 軽量化後のポリゴンモデル

\section{5 まとめ}

本論文では，QEM 手法を PC クラスタ環境で動作さ せるための分散化手法について述べた . 本手法は , 軽量 化終了条件を与える閾値を計算し，乥れに基づいて各 サーバが個別に軽量化できるようなアルゴリズムを導入 した . また , クライアント・サーバ間の通信コストを削 減するために，軽量化処理を 2 パスにし，1 パスの場合 と比較して, 軽量化結果に影響がほとんどないことも確 認した．本手法により，1 台での処理と比較して，8 台 の PC により，形状によっては約 18.2 倍の高速化を達 成できた . 今後の課題としては, 形状に応じた適切な領 域分割手法の提案と，巨大なデータによる実験を行なう ことである .

\section{参考文献}

[1] M. Garland and P. S.Heckbert: "Surface Simplification Using Quadric Error Metrics" , Proc, SIGGRAPH' 97, pp.209-216, 1997.

[2] D. P. Luebke: "A Developer's Survey of Polygonal Simplification Algorithms" ,Computer Graphics and Applications, May/June, pp.24-35, 2001.

[3] Y. Yoshida, K. Konno, and Y. Tokuyama "A Dis- tributed Simplification Algorithm with PC Cluster", IWAIT 2006, pp.121-126, 2006.

[4] N. Hashimoto, Y. Ishida, and M. Sato: "A Self-Adaptive Software Environment for ClusterBased Display System", IWAIT 2005, pp.417422, 2005.

[5] W. T. Correa, J. T. Klosowski, and C. T. Silva: "Out-Of-Core Sort-First Parallel Rendering for Cluster-Based Tiled Displays" ,In Proceedings of PGV 2002 (4th Eurographics Workshop on Parallel Graphics and Visualization), pp.89-96, 2002.

[6] 藤原慎也, 今野晃市, 曽根順治, 德山喜政: “階層化 境界球群を用いた正確な衝突面検出法”，画像電子 学会誌, Vol.35, No.1, pp. 20-29, 2006.

[7] J. El-Sana and A. Varshney: "Parallel Construction and Navigation of View-Dependent Virtual Environments” „Proc. SPIE'99 Conference on Visual Data Exploration and Analysis, pp.23-29, 1999.

[8] P.Cignoni, C. Rocchini, and R. Scopigno : "Metro:measuring error on simplified surfaces", Computer Graphics Forum , Vol.17 „No.2 ,pp.167$174,1998$.

[9] H. Hoppe: "Progressive Meshes" , Proc, SIGGRAPH' 96, pp.99-108, 1996.

[10] Charles Teorell Loop: "Smooth Subdivision Sur- 
芸術科学会論文誌 Vol. 7 No. 3 pp. $113-123$

faces Based on Triangles", Master's thesis, University of Utah, 1987. 